\title{
Business Challenges in Changing Environment and its Financial Implications for CSR: A Review
}

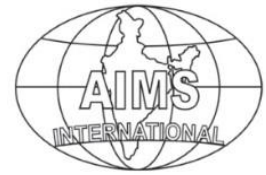

DOI: $10.26573 / 2020.14 .3 .4$

Volume 14, Number 3

September 2020, pp. 171-190

\author{
Nitika Gaba \\ R. Madhumathi \\ DOMS, IIT Madras \\ (nitikagaba1@gmail.com) \\ (rmm@iitm.ac.in)
}

The implications for CSR due to changing global corporate environment are a pertinent issue for all the stakeholders. The global financial crisis necessitated the way corporations has catalyzed and focused on sustainability. The paper theoretically and empirically addresses the relationship between CSR and its financial implications from literature. The theoretical relationship of CSR with financial performance such as agency theory, stakeholder theory, and legitimacy theory is well established, however the empirical analysis identifies positive correlation with accounting based measures as compared to market based measures. The conclusion justifies the need for future research on measuring financial risk for CSR and the degree of financial frictions and institutional settings in evaluating CSR cost.

Keywords: Corporate Social Responsibility, Stakeholders, Earnings

Management, Tax avoidance, Capital Structure

\section{Introduction}

In dynamic economic environment, corporations can no longer act as isolated economic entities operating in isolation from the society. Of late, the traditional view of competitiveness, survival and profit has become redundant (IISD, 2019). This has led to growth in demand for greater disclosure, increased customer interest and investor pressure leading to the exploration of voluntary and non-voluntary initiatives in disclosing social and environmental objectives. The financial crisis of 2008 has highlighted the need for corporations to help the government in developing sound policy and regulatory frameworks. In this changing era, all the development challenges are positively correlated with corporate challenges. A few decades ago, the major development challenge was only economic disparity i.e. transforming the lives of people in poorer countries to reach the standard of those living in developed countries. Despite advancements in emerging economies underdevelopment in urban and rural areas is still a challenge for economies. The participation of corporations to the economic development is through the corporate social responsibility (CSR). CSR may not solve all economic challenges being faced by corporations but by investing in areas like research and development, community relations it can give just the right push to make the world a better place to live in. Academic interest in social responsibility of business has grown significantly over the years on variety of topics related to finance and economics like impact of role of board and foreign ownership, 
firm debt maturity, credit rating, stock returns on CSR. Several management theories assume that an objective of a corporation is to maximize its profit subject to constraints where shareholder acts as a key agent by providing the financial resources for the corporate operations (Jensen and Meckling, 1976; Zingales, 2000). However, there are two schools of thought existing among scholars on meeting the need of the stakeholders, "by doing well by doing good" (Porter and Kramer, 2011). The corporation creates value for shareholders by avoiding situations like consumer boycotts and paying fines to the government. In contrast, another group of scholars debate that adopting environment and social policies can destroy shareholder wealth (Friedman, 1970, Navarro, 1988). Their argument like that of Jensen and Meckling (1976) iterates the agency cost implications of sustainability. The 'stakeholder approach' is gaining momentum and is replacing the 'shareholder value' to curb the challenges being faced by the corporations. The late 1990s came up with the concept of triple bottom line by Eklington (1997) which focuses not only on economic value that the corporations can add, but also on the environmental and social value that they add or destroy. Svensson (2018) found from their crossindustrial studies in Norway and Spain that the triple bottom line's economic element has a direct effect on the environmental element with the social element mediating this effect.

One of the most debated topics about CSR is the relationship between corporate social performance (CSP) and corporate financial performance (CFP). For more than forty years, the link between CSP and CFP is still not established clearly. Margolis et al. (2009) collected more than 200 studies on this question in their meta-analysis and observed that $59 \%$ of these studies revealed the non-significant relationship, $2 \%$ negative relationship and $28 \%$ a positive relationship. There is a need to extend our comprehension of the implications of CSR. Stakeholders wish to know whether CSR can affect methodology of how a corporation manages earnings, risk and financing decisions. The CSR-CFP relationship in the literature has led to the development and the emergence of other avenues of research. These arguments encourage an important body of literature that includes the impact of CSR on earnings management (Chih et al, 2008; Yip et al, 2011\& Kim et al. 2012), financial reporting (Andrikopoulos et al, 2014\& Carey, Liu \& Qu, 2017) cost of capital and capital structure (Ng and Razaee et al, 2015\& Girerd-Potin et al, 2011) and tax-avoidance (Huseynov\& Klamm, 2012 \& Preusse, 2010).

In this paper, we present a literature review $(n=63)$ on the corporation's financial implications in relation to CSR. We discuss the theoretical and empirical viewpoints on the impact of CSR on financial reporting, earnings quality, tax avoidance and cost of capital and capital structure. The qualitative assessments of empirical results provide an overview of current research and directions for future research.

\section{CSR and Financial Reporting}

Arguments persist as to how corporations have adopted CSR into their financial reporting to project a high audit quality standard as compared to those corporation's that have not adopted CSR. There is a perception that positive image flows to a corporation's reputation, such as less financials risk and high earning. Existing literature on testing this hypothesis reveals that the way CSR is reported has changed during the recession by becoming a mechanism by which a corporation can survive. 
After the recession, the corporate sector has made limited progress in truly integrating CSR into core corporate activities (Ellis \& Bastin, 2010). Andrikopoulos et al. (2014) found that the extent of disclosure of CSR practices is greater in larger corporations and in corporation's that have high financial leverage. The significant properties of the disclosure are not related to its quantity, but content. Patten \& Zhao (2014) argued with Guthrie et al. (2008) analysis that the corporation's in their sample focus more on discussing programs and initiatives than on providing relevant performance data. Environment disclosures on an average were the most prominent CSP reporting issue. The socially responsible mutual fund stock holdings of reportissuing firms increased following the first-time release of the standalone report but that the change was not statistically significant. Ballou et al. (2018) noted that CSR assurance improves CSR reporting quality by identifying inaccuracies in prior reports and improvements to definitions, scopes and methodologies that require restatements for comparability.

Accounting providers are not more likely to identify reporting inaccuracies, but they do promptly prevent future inaccuracies. They also report that adopting CSR reporting frameworks like Global reporting initiative (GRI) is not a substitute for obtaining CSR assurance in terms of improving reporting quality. It can help to enhance CSR reporting quality through prompting non-error restatements. Tschopp \& Huefner, R (2014) used Carnegie and Napier's seven factors (Period, Places, People, Practices, Propagation, Products and Profession) that allow for a systematic comparison between the evolution of financial reporting and CSR reporting. Financial reporting has evolved over the last 100 years but still, there are limitations within existing standards. Relative to this, CSR reporting is still in its infancy. They argued that the GRI G4 is the most widely used method of CSR reporting, but still merely two-third of reporting corporation's in the KPMG survey do not use this standard which makes it difficult to compare various CSR reports (KPMG, 2017). In terms of products and practices, some attempts are made towards CSR reporting harmonization but there are opponents to it which says that one standard does not meet the needs of all stakeholders. The profession factor recognized that major CSR organizations appear to be more interconnected and supportive of one another. The propagation factor demonstrated that external organizations and bodies have played a key role in promoting and legitimizing financial reporting on CSR related issues whose goals includes sustainable development. IFRS has almost become the global standard in financial reporting but a lot of work is to be done before CSR reporting is accepted on a global scale (Tschopp and Huefner, 2014). The people factor highlights that the number of stakeholders has evolved in the process.

Wang et al. (2016) analyzed another dimension of this aspect that mandatory CSR disclosure corporations constrain earnings management which suggests that mandatory CSR disclosure mitigates information asymmetry by improving financial reporting quality. Carey et al. (2017) support the audit-risk perspective in explaining the positive association between voluntary CSR disclosure and higher audit fees in China which is more significant for non-state owned corporations, indicating that CSR reporting by such corporation's is used more as a mechanism to create the appearance of legitimacy and integrity, rather than an honest expression of commitment to stakeholders. Those corporations which issue stand-alone CSR reports were associated with more earnings management. Michelon et al. (2015)'s 
results indicated that the use of CSR reporting practices is not related to high disclosure quality implying that these practices are symbolic, rather than substantive. However the corporation's which follow GRI guidelines and those corporation's which are conditional on reporting information on results (usually bigger companies with more active stakeholder engagement processes) are providing more complete information.

Table 1 Financial Reporting: Variables, Issues, Relationship, Evidence

\begin{tabular}{|c|c|c|c|c|}
\hline Variables & Issues & Relationship & Evidence & Reference \\
\hline $\begin{array}{l}\text { Corporate social } \\
\text { responsibility } \\
\text { disclosure index } \\
\text { (CSRDI) }\end{array}$ & \begin{tabular}{|l|} 
Firm profitability, \\
size, leverage and \\
market to book ratio \\
impact on disclosure
\end{tabular} & $\begin{array}{l}\text { Positive relation } \\
\text { with all four factors }\end{array}$ & $\begin{array}{l}\text { Disclosure is greater in } \\
\text { large companies and } \\
\text { companies with higher } \\
\text { financial leverage. }\end{array}$ & $\begin{array}{l}\text { Andrikopoulos } \\
\text { et al. (2014) }\end{array}$ \\
\hline $\begin{array}{l}\text { Standalone CSR } \\
\text { reporting }\end{array}$ & US retail industry & $\begin{array}{l}\text { Positive and } \\
\text { negative effect of } \\
\text { such reporting on } \\
\text { reputation }\end{array}$ & $\begin{array}{l}\text { Only public limited } \\
\text { companies disclose. } \\
\text { Reports are more about } \\
\text { image enhancement than } \\
\text { transparent accountability. }\end{array}$ & $\begin{array}{l}\text { Pattenx\& Zhao } \\
(2014) \\
\text { Michelon et al } . \\
(2015)\end{array}$ \\
\hline $\begin{array}{l}\text { Reporting } \\
\text { evolution }\end{array}$ & $\begin{array}{l}\text { Period, Place, } \\
\text { People, Practices, } \\
\text { Propagation, } \\
\text { Products \& } \\
\text { Profession }\end{array}$ & $\begin{array}{l}\text { Diversified } \\
\text { reporting }\end{array}$ & $\begin{array}{l}\text { Evolution to market-based } \\
\text { reporting }\end{array}$ & $\begin{array}{l}\text { Tschopp and } \\
\text { Huefner ( 2014) }\end{array}$ \\
\hline Assurance & $\begin{array}{l}\text { CSR assurance } \\
\text { improves reporting } \\
\text { quality }\end{array}$ & Positive effect & $\begin{array}{l}\text { CSR assurance identifies } \\
\text { inaccuracies in prior } \\
\text { reports and provides } \\
\text { improvements }\end{array}$ & $\begin{array}{l}\text { Ballou et al. } \\
(2018)\end{array}$ \\
\hline Estimation model & $\begin{array}{l}\text { Impact of mandatory } \\
\text { CSR reporting }\end{array}$ & $\begin{array}{l}\text { Mandatory CSR } \\
\text { constrain earnings } \\
\text { management }\end{array}$ & $\begin{array}{l}\text { Mandatory CSR disclosure } \\
\text { mitigates information } \\
\text { asymmetry }\end{array}$ & $\begin{array}{l}\text { Wang et al. } \\
(2016)\end{array}$ \\
\hline
\end{tabular}

The literature on financial reporting highlights its usage as a mechanism to avoid information asymmetry. More environmental disclosures are emphasized by corporations. Though, corporations may not adhere to standard procedure to report CSR, GRI guidelines help in quantifying the qualitative CSR information. The increase in CSR reporting of the corporations worldwide is encouraging but because of different laws and codes of transparency, there is an astounding variation in what is reported and for whom it is reported as only a few corporations discuss their policy and initiatives on relevant programs. An aspect of CSR disasters could be evaluated where some events prompt attention for some sort of CSR performance. There could be window dressing induced by CSR disasters which can have some effect on financial reporting quality. For example, managers may manipulate payments by 
strategically timing the funding of their corporation's charitable foundations to increase earnings to report small positive changes or create reserves. These foundations offer an opportunity for manager discretion to influence reported earnings without necessarily affecting the level of commitment to outside charities (Petrovits, 2006).

\section{CSR and Earnings Quality}

Like relationship between CSR and financial reporting, one finds different opinion on the relationship between CSR, earning quality and management. Corporate transparency and accountability are very important issue for stakeholders. Earnings quality can provide useful information about the financial performance of corporations (Dechow et al, 2010). As we know that, earnings management occurs when managers start using judgment in financial reporting. We analyze the CSR and earnings management relation in the forthcoming discussion by analyzing recent studies by the scholars on same area.

Grougiou et al. (2014) addressed that in US banks, there is no bi-directional relationship between CSR and earnings management (EM). CSR is driven by EM while CSR engagement does not affect EM. Gras-Gil et al. (2016) stated that in Spain, 100 most reputable corporations of Merco Index showed a negative relation of CSR with EM. Also, the corporations which were more committed to CSR were less engaged in EM. Liu et al. (2017) examined how family involvement in the ownership management or governance of business affects its engagement both directly and indirectly through its CSR activities. They found that CSR is not significantly associated with both real and accrual -based earnings management behavior after accounting for the effect of family involvement. It reveals that scholars have not found any positive relationship between CSR and EM when they took family involvement as variable in their respective study. Alipour et al. (2019) found consistent results with Hong \& Anderson (2011) that CSR is related to higher accruals quality and confirms ethical behavioral theory in Iran. Their study was in line with a strategic view that defines a positive relationship between environmental quality disclosure and earnings persistence.

Ben Amar et al. (2018) analyzed 119 French non-financial corporations from 2010-2014 and found a negative impact of CSR on EM in line with the results of Litt et al. (2014), Almahrog et al. (2018) reported on labor relation that the fairness of practice and community involvement did not influence EM. Moreover, corporate governance, respect for human rights, good environmental management and meeting consumer expectations all have significant negative impacts on earnings management. In addition, Muutakin et al. (2015) concluded results in consent to the stakeholder theory with their sample of 135 corporations listed on Dhaka stock exchange that a corporation is influenced by different stakeholder groups in the society and reports its activities through CSR disclosures. Sial et al. (2018) reported that earnings management has a negative moderate relationship between CSR and corporate performance. A high value of earnings management, which results in a high level of symbolic CSR, converts to low corporate performance of the Chinese corporations. CSR actions promoted by managers cover their profit management and incite an adverse effect on the corporation's performance. Suyono, (2018) through their sample of manufacturing corporation's on Indonesian stock exchange found 
that institutional ownership, managerial ownership, and independent boards have a significant deterrent effect on earnings management. There was a strong moderation effect on earnings management and a positive link between governance and CSR. Bona Sanchez et al. (2017) stated a positive relationship between sustainability reporting and earnings in formativeness as the dominant owner's voting-cash flow wedge increases. Becchetti et al. (2013) demonstrated that high CSR quality in terms of accounting transparency, high corporate governance quality, stakeholder risk mitigation and absence of over-investment contributes to making earnings forecasts unbiased in US. Bozzolan et al. (2015) provided evidence that CSR is negatively associated with the use of earnings management strategies in an international setting. CSR orientation of the corporations interacts with the characteristics of the institutional environment such as legal enforcement in shaping the reporting incentives in a global context. Lars Moratis \& Max Van Egmond (2018) findings show a positive insignificant relationship between CSR and EM from 2003-2009 in US- listed corporations. Corporations in industries that have a high environmental impact tend to have higher levels of CSR performance, this corporation's practice EM to a lesser extent than corporations in industries that have a lower environmental impact (Chih et al, 2008, Kim et al, 2012).

Garcia et al. (2017) reported that CSR activities improve the bank's earnings quality. Ethics, reputation, and financial performance motivations justify the positive influence of CSR activities on banks' earnings quality. Thus, socially responsible banks committed to a higher level of CSR practices are likely to provide investors and debt holders with persistent disclosure of earnings and figures that allow managers to predict future cash flows.

Financial scandals have shaken up the business world as information asymmetry and dishonest auditing practices can lead managers to exercise discretion which opposes the interests of the owner. Due to this, corporations implementing CSR activities are bound to provide transparent and reliable financial information (Kim et al. 2012). Theoretical foundations on CSR-EM relationship is usually pinned by legitimacy theory, agency theory, social-norm theory, stakeholder theory and signaling theory. Some researchers say that CSR expenditure by corporations is induced by long-term perspectives on sustainable corporate operations while some say that CSR is used as a shield to hide manager's opportunistic activities. Further studies can employ behavioral frameworks to examine the motives of managerial strategies including CSR and EM. Non-linear relationship between CSR and EM can also be considered by researchers in future studies. India ranks third globally in terms of number of family owned businesses (Credit Suisse, 2018), an investigation into family involvement in influencing CSR-EM relationship can provide different insights in extension of the work of Liu et al. (2017). Alipour et al. (2019) showed results consistent with ethical theories which describe CSR as a tool defining ethical standard to achieve goals both in theory and practice (Matten, 2004). Litt et al. (2014) used two theoretical frameworks- external monitoring theory and internal corporate culture theory to study the relationship between environmental initiatives and earnings management and supported the hypothesized significant negative relationship between the two. More proxies of earnings management like financial restatement, fraud, and analyst forecasts and earnings conservatism can be used by future researcher's though studies have predominantly used discretionary accruals. 
The role of EM as a moderating variable between CSR and financial performance could be evaluated in developing countries. Evaluation of existence of real earnings management activities in addition to conservative financial reporting to mitigate CSR compliance costs can lead to different insights.

Table 2 Earnings quality: Variables, Issues, Relationship, and Evidence

\begin{tabular}{|c|c|c|c|c|}
\hline Variables & Issues & Relationship & Evidence & Reference \\
\hline $\begin{array}{l}\text { Loan Loss Provisions } \\
\text { deflated by total loans, } \\
\text { Realized security gains and } \\
\text { losses deflated by total } \\
\text { assets }\end{array}$ & $\begin{array}{l}\text { Bi-directional } \\
\text { relationship between } \\
\text { CSR and earnings } \\
\text { management }\end{array}$ & $\begin{array}{l}\text { EM and } \\
\text { CSR=Positive } \\
\text { relation } \\
\text { CSR and } \\
\text { EM=Negative } \\
\text { relation }\end{array}$ & $\begin{array}{l}\text { Legitimacy theory. } \\
\text { Differentiation strategy }\end{array}$ & $\begin{array}{l}\text { Grougiou et } \\
\text { al. (2014) }\end{array}$ \\
\hline $\begin{array}{l}\text { Discretionary (Abnormal } \\
\text { accruals) }\end{array}$ & $\begin{array}{l}\text { CSR and earnings } \\
\text { management }\end{array}$ & Negative impact & $\begin{array}{l}\text { Effective use of } \\
\text { resources }\end{array}$ & $\begin{array}{l}\text { Gras-Gil et } \\
\text { al. (2016) } \\
\text { Almaharog } \\
\text { et al. (2018) } \\
\text { Litt et al. } \\
(2014) \\
\end{array}$ \\
\hline Discretionary accruals & $\begin{array}{l}\text { Influence of } \\
\text { corporate } \\
\text { governance on CSR } \\
\text { \& EM }\end{array}$ & Positive impact & $\begin{array}{l}\text { CSR disclosure covers } \\
\text { up EM practices. }\end{array}$ & $\begin{array}{l}\text { Suyono et } \\
\text { al.(2018), } \\
\text { Muttakin et } \\
\text { al. (2018) }\end{array}$ \\
\hline $\begin{array}{l}\text { Accrual based earnings } \\
\text { management (AEM) } \\
\text { Real earnings management } \\
(\text { REM) }\end{array}$ & $\begin{array}{l}\text { Family involvement } \\
\text { in the ownership }\end{array}$ & $\begin{array}{l}\text { Family firms= } \\
\text { Less AEM } \\
\text { REM= No } \\
\text { significant } \\
\text { relationship } \\
\end{array}$ & $\begin{array}{l}\text { If family involvement is } \\
\text { controlled, CSR impact } \\
\text { is nil }\end{array}$ & $\begin{array}{l}\text { Liu et al. } \\
(2017)\end{array}$ \\
\hline Earnings persistence & $\begin{array}{l}\text { CSR practices } \\
\text { enhances earnings } \\
\text { quality }\end{array}$ & Positive relation & \begin{tabular}{|l|} 
More socially \\
responsible banks have \\
more earnings quality in \\
a stricter environment. \\
\end{tabular} & $\begin{array}{l}\text { Garcia et al. } \\
(2017)\end{array}$ \\
\hline Unbiased forecast & $\begin{array}{l}\text { CSR \& earnings } \\
\text { forecast }\end{array}$ & Positive relation & $\begin{array}{l}\text { High CSR quality makes } \\
\text { earnings forecast } \\
\text { unbiased }\end{array}$ & $\begin{array}{l}\text { Becchetti et } \\
\text { al. (2013) }\end{array}$ \\
\hline $\begin{array}{l}\text { Earnings smoothening, } \\
\text { earnings aggressiveness, } \\
\text { earnings losses avoidance }\end{array}$ & $\begin{array}{l}\text { CSE and earnings } \\
\text { characteristic }\end{array}$ & $\begin{array}{l}\text { Negative } \\
\text { relations }\end{array}$ & $\begin{array}{l}\text { Commitment to CSR } \\
\text { improves earnings } \\
\text { characteristics }\end{array}$ & $\begin{array}{l}\text { Chih et al. } \\
(2008)\end{array}$ \\
\hline
\end{tabular}

\section{CSR, Cost of Capital and Capital Structure}

Literature on the relationship between CSR and capital structure relationship show mixed reaction among scholars. Richardson and Welker (2001) made an early attempt to see the social disclosure impact on the cost of capital with their sample of Canadian corporations and found a statistically significant and positive relationship between the level of social disclosure and the cost of capital for the corporation but they were unclear about their results due to the period of study and biases in social disclosures. Sherfman and Fernando (2008) predicted that the market would reward the corporations improved risk position through lowered costs of debt and equity capital and provides theoretical arguments that why a corporation that engages in environmental risk management experiences enhancement in cost of debt and equity capital. The cost increase is partially offset by higher tax benefits, but net results are 
the same. Three reasons for this contrary result are punishing corporations engaging in investments in environmental risk management more than compliance requirements, difficulty in separation of the effect on the cost of debt of high leverage from that of high environmental risk management as more debt is offered to corporations with high environmental risk management and also there is a little demand for debt from socially screened investors (Mackey et al, 2007). Ng \& Rezaee (2015) examined the effect of different dimensions of business sustainability performance on the cost of equity. They found that economic sustainability performance pertaining to growth opportunities and research efforts are negatively and significantly related to cost of equity capital while operational efficiency is positively associated with cost of equity capital. Their paper also tested interactive effects between economic and environmental, social and governance (ESG) sustainability performance on cost of equity and found that the relation between economic performance and cost of equity is strengthened when ESG sustainability performance is strong, but the relationship is mainly contributed by social sustainability performance. Dhaliwal et al. (2011) findings indicate that the corporations with high cost of capital in the previous year tend to initiate disclosure of CSR activities in the current year and the corporations with CSR performance superior to its industry peers enjoy a reduction in the cost of capital after they initiate CSR reports. Further, corporations initiating CSR disclosure with superior CSR performance attract dedicated institutional investors and analyst coverage, and these analysts achieve lower absolute forecast errors and dispersion following such disclosure.

Suto \& Takehara, (2017) found insufficient evidence of negative link between the level of corporate social performance (CSP) and the cost of equity. Yang et al. (2018) found that the effect of CSR on leverage is slow, creditors are willing to tolerate corporations that deviate from their target capital structure, especially abovetarget leverage corporations. The corporations that issue CSR statements exhibit slower capital structure adjustment, and that above-target leverage corporations that issue CSR statements have lower incentives than below-target leverage corporations to return to the target leverage and CSR statements improve long-term leverage but do not affect short-term leverage. Bae et al. (2011) supported Maksimovic and Titman (1991), that the stakeholders are reluctant to do business with a highly levered corporation because it can hinder in honoring the implicit contracts. GirerdPotin et al. (2011) also found no relationship between the corporation's social score and its cost of debt, suggesting that banks do not adjust their interest rates to corporation social ratings. They show that debt financing is a way for corporations with low social commitment on the corporation's cost of capital. Harjoto and Jo (2014) with their sample of US public corporations found that overall CSR intensities reduce analyst dispersion of earnings forecast, volatility of stock return and cost of capital (COC) and increase corporation value. However, its impact is reduced for corporations with better accounting and disclosure quality. The legal (normative) CSR decreases analyst's dispersion, stock return volatility, and COC, while legal (normative) CSR increases corporation value. Most of the studies establish a negative relationship between CSR and cost of capital as expenditure on CSR creates a competitive advantage and transparency. Better stakeholder engagement lowers the cost of capital that helps in value creation as CSR has 
significant impact on the capital allocation process. This is because market participants are more willing to allocate scarce capital resources to corporations with better CSR performance (Cheng, Ioannou \& Serafeim, 2013). Future studies can extend the relationship between cost of capital and CSR based on the degree of financial frictions they face. Impact of loan covenants can be studied for banks as they can present an alternative explanation of the modest impact of CSR on loan pricing. As most of the CEOs are considering CSR strategically critical, expansion of CSR and cost of capital relationship will be beneficial to the corporations. Difference in institutional settings and legal environment could be explored. Impact of CSR on equity holders and debt holders can be examined differently as they have a different payoff function. Mandatory CSR spending affect creditor's perceptions and cost of debt could also be examined.

Table 3 Cost of Capital \& Capital structure: Variables, Issues, Relationship and Evidence

\begin{tabular}{|c|c|c|c|c|}
\hline Variables & Issues & Relationship & Evidence & Reference \\
\hline \begin{tabular}{|l|} 
Book value of \\
equity, \\
forecasted \\
.return on \\
equity, terminal \\
value, earnings \\
forecasts, ROE \\
\end{tabular} & $\begin{array}{l}\text { Financial \& social } \\
\text { disclosure \& the cost } \\
\text { of equity capital }\end{array}$ & $\begin{array}{l}\text { Significant } \\
\text { positive relation } \\
\text { between social } \\
\text { disclosures \& } \\
\text { cost of equity } \\
\text { capital }\end{array}$ & $\begin{array}{l}\text { Negatively related } \\
\text { to cost of equity } \\
\text { capital for firms } \\
\text { with low analyst } \\
\text { following }\end{array}$ & $\begin{array}{l}\text { Richardson } \\
\text { \& Welkar } \\
(2001)\end{array}$ \\
\hline $\begin{array}{l}\text { CAPM, } \\
\text { marginal cost } \\
\text { of borrowing }\end{array}$ & $\begin{array}{l}\text { Environmental risk } \\
\text { management \& the } \\
\text { cost of capital }\end{array}$ & Negative relation & $\begin{array}{l}\text { Firms benefit from } \\
\text { environmental risk } \\
\text { management as they } \\
\text { shift from equity to } \\
\text { debt \& have tax } \\
\text { benefits }\end{array}$ & $\begin{array}{l}\text { Sherfman } \\
\text { and } \\
\text { Fernando } \\
(2008) \\
\text { Suto \& } \\
\text { Takehara, } \\
(2017)\end{array}$ \\
\hline $\begin{array}{l}\text { Implied cost of } \\
\text { equity capital, } \\
\text { market price } \\
\text { and dividend }\end{array}$ & $\begin{array}{l}\text { Voluntary disclosure } \\
\text { of CSR activities }\end{array}$ & $\begin{array}{l}\text { High cost of } \\
\text { equity capital in } \\
\text { the previous } \\
\text { year= More } \\
\text { disclosure of CSR } \\
\text { activities }\end{array}$ & $\begin{array}{l}\text { CSR is associated } \\
\text { with a higher prior } \\
\text { year cost of equity } \\
\text { capital }\end{array}$ & $\begin{array}{l}\text { Dhaliwal et } \\
\text { al.(2011) }\end{array}$ \\
\hline $\begin{array}{l}\text { Equity } \\
\text { premium }\end{array}$ & $\begin{array}{l}\text { legal \& normative } \\
\text { CSR on the analyst's } \\
\text { earning forecast } \\
\text { dispersion, stock } \\
\text { return volatility, cost } \\
\text { of equity capital \& } \\
\text { Cost of capital } \\
\end{array}$ & Negative relation & $\begin{array}{l}\text { CSR intensities } \\
\text { increases firm } \\
\text { value. }\end{array}$ & $\begin{array}{l}\text { Harjoto and } \\
\text { Jo (2014) }\end{array}$ \\
\hline $\begin{array}{l}\text { Expected return } \\
\text { model }\end{array}$ & $\begin{array}{l}\text { Impact of dimensions } \\
\text { of sustainability } \\
\text { performance on cost } \\
\text { of equity capital }\end{array}$ & Negative relation & $\begin{array}{l}\text { Reduced cost of } \\
\text { capital improves } \\
\text { financial \& non- } \\
\text { financial } \\
\text { sustainability }\end{array}$ & $\begin{array}{l}\mathrm{Ng} \& \\
\text { Rezaee } \\
(2015)\end{array}$ \\
\hline
\end{tabular}




\section{CSR and Tax Avoidance}

Tax avoidance like other socially irresponsible activities needs to be addressed by academics. Lack of ethical discussion as compared to human rights and environmental issues may be the reason for very few research publications. It poses costs to people outside the corporations that outweigh the benefits. However, the loss of public trust and recession has widened the interest in corporate tax payment behavior. Corporations affect the society economically, socially and environmentally and paying tax is the economic expectation which cannot be ignored for long-term survival and stability (OECD, 2020).

Some researchers point out that corporations take advantage of tax havens to maximize shareholder wealth while those who support CSR iterate that CSR can provide conceptual framework for corporations to adopt anti-tax avoidance practices.

Generally, there is perception among stakeholders that CSR reduces tax avoidance. The decrease in tax expense can be viewed as an increase in profitability but tax avoidance can also be viewed as social irresponsibility as a corporation is not giving its contribution to support government social programs. Huseynov \& Klamm (2012) were the first to study empirically tax avoidance, tax management and CSR literature. By separating the strengths and concerns for each CSR measure, they found that the interaction of community concerns with tax management fees positively affects both GAAP and cash effective tax rate (ETR), while the interaction of corporate governance strengths and diversity concerns with tax management fees negatively affects cash ETR. They also concluded that additional evidence that CSR affects tax avoidance when they divide corporations into portfolios based on CSR levels. Dowling (2013) started a debate in mainstream business ethics literature about the fundamental assumptions and boundary conditions of CSR in the context of tax avoidance through questioning if CSR blindly adheres to the government policy. Hasseldine \& Morris, (2013) is a response to the study of Sikka, P (2010) paper on "Smoke and Mirrors: Corporate Social Responsibility and Tax Avoidance" by explaining the importance of distinguishing the terms "tax evasion" and "tax avoidance" in context of CSR arguing that some corporations that claim to be socially responsible are also engaged in tax avoidance similar to Preusse (2010). Laguir, Staglianò \& Elbaz, (2015) used a structured model using partial least squares regression and measured tax aggressiveness as a latent construct using items based on effective tax rate (ETR) for a sample of French publicly listed corporations and found that greater the activity in the social dimension of CSR, the lower the level of corporate tax aggressiveness will be, whereas high activity in the economic dimension is associated with a high level of tax aggressiveness. Whait et al. (2018) revealed in their analysis that there is a lack of general agreement over the definition of tax aggressiveness and CSR and not all dimensions of CSR have been addressed. Lanis and Richardson (2014) used logit regression to demonstrate that higher the level of CSR performance, lower the likelihood of tax avoidance in line with Hanlon and Heitzman (2010). Bird and Davis-Nozemack (2018) suggested that tax avoidance should be framed as a global sustainability problem as it effectively erodes common social and environmental resources.

Enron case indicates that the drive to manipulate book profits fosters tax avoidance leading to managerial malfeasance. Because of corporate malfeasance, corporate tax avoidance is not fully valued in the stock market by investors (Mihir A 
Desai, 2005). Thus, if tax avoidance is approached as a CSR issue, the risk will be mitigated by not driving tax advisors to more tax avoidance strategies. The two main theories linking CSR and tax avoidance are the corporate culture and risk management theories. The corporate culture theory argues that all the decisions of the corporation should reflect the right behavior. This theory states that a corporate should not engage simultaneously in activities that might not be good for the society. Corporate tax avoidance increases the cost for the society (Weisbach, 2002); still it is rarely seen in relation to CSR (Kreps, 1996) which theorizes negative relationship between CSR scores and tax avoidance practices. On the other hand, risk management theory discusses that corporations spend on CSR activities to hedge against any reputational risks arising from tax avoidance practices (Godfrey, 2005). The literature suggests that the link between CSR and tax avoidance is nascent and there is also lack of reliable tax data. (Sikka, 2010). Most studies have used offshore tax havens data to categorize corporations as tax avoiders. Recent papers have formulated suggestions to incorporate taxes into the definition of CSR (Col and Patel, 2016, Sikka, 2010). This is also reflected in Dow Jones Sustainability Index (Bird \& Davis-Nozemack, 2018). Yvonne (2014) used a case study of a MNC which shows how transfer pricing mechanism is used for tax avoidance. This was a response to the study of Hasseldine and Morris (2013) for studying corporations having history of fraud. Case study was used because corporate financial reports rarely disclose any transfer pricing practices (Sikka, 2010). The case study provided a lucid real-world account of how a corporation engages in tax avoidance through transfer pricing. Hasseldine and Morris (2013) say that Sikka (2010) used only few examples to explain the research outcome criticizing taxation practices and CSR of a corporation. They instead talk about three factors i.e. intention of the actor, knowledge of application of tax code and propensity of the actor to apply the tax code. Sikka (2013) responded that Hasseldine and Morris (2013) fail to see corporations as an active player in social conflict as they assume that state is diverse. They fail to cite even one example of a corporation whose tax practice was in consensus with its CSR statements. Laguir, Staglianò \& Elbaz (2015) concluded that corporation's tax aggressiveness depends upon the nature of the CSR activities of which it engages in. They state that corporations engaging in the CSR activities of human resources, human rights in workplaces and community involvement were less likely to engage in tax aggressiveness while those corporations which engage in CSR activities related to corporate behavior were more likely to engage in tax aggressiveness.

\section{Conclusion and Research Gaps}

A key contribution from this paper is that it shows different approaches in addressing relationship with corporate social responsibility. Many scholars have analyzed different variables of CSR separately. The present study evaluated each variable closely. This generates opportunities for future research. The literature review of the studies on financial implications of CSR suggests that there are more variables used in financial reporting and EM. Studies used very few variables in capital structure and tax avoidance relation with CSR (Figure 1). Figure 2 shows that number of papers on the four variables has increased over the years. Studies on financial reporting and CSR highlighted the fact that there is more disclosure by corporations having high leverage but CSR disclosure not necessarily ensures CSR performance 
Table 4 Tax Avoidance: Variables, Issues, Relationship \& Evidence

\begin{tabular}{|l|l|l|l|l|}
\hline \multicolumn{1}{|c|}{ Variables } & \multicolumn{1}{|c|}{ Issues } & Relationship & \multicolumn{1}{c|}{ Evidence } & \multicolumn{1}{c|}{ Reference } \\
\hline $\begin{array}{l}\text { GAAP } \\
\text { effective tax } \\
\text { rate, Cash } \\
\text { effective tax } \\
\text { rate, Tax fee } \\
\text { rate }\end{array}$ & $\begin{array}{l}\text { The effect of corporate } \\
\text { governance, } \\
\text { community \& diversity } \\
\text { on tax avoidance in } \\
\text { firms that use auditor } \\
\text { provided tax services }\end{array}$ & $\begin{array}{l}\text { Tax } \\
\text { management } \\
\text { fees= Positive } \\
\text { Effect on } \\
\text { GAAP \& Cash } \\
\text { ETR= Negative }\end{array}$ & $\begin{array}{l}\text { CSR effects tax } \\
\text { avoidance when the } \\
\text { firms are divided } \\
\text { into portfolios on the } \\
\text { basis of CSR levels }\end{array}$ & $\begin{array}{l}\text { Huseynov \& } \\
\text { Klamm (2012) } \\
\text { Laguir, Staglianò \& } \\
\text { Elbaz, (2015) }\end{array}$ \\
\hline $\begin{array}{l}\text { Offshore } \\
\text { finance } \\
\text { centre's or Tax } \\
\text { havens }\end{array}$ & $\begin{array}{l}\text { Companies location } \\
\text { and socially } \\
\text { responsible }\end{array}$ & Positive relation & $\begin{array}{l}\text { Fall short of } \\
\text { expectations }\end{array}$ & Preusse (2010) \\
\hline Tax dispute & $\begin{array}{l}\text { CSR and corporate tax } \\
\text { avoidance }\end{array}$ & $\begin{array}{l}\text { Negative } \\
\text { relation }\end{array}$ & $\begin{array}{l}\text { CSR that reduces tax } \\
\text { avoidance }\end{array}$ & Lanis and \\
Richardson (2014)
\end{tabular}

(Wang et al, 2018). Corporations should elaborate in their reporting process how they identify and address stakeholder concerns while giving attention to various environmental, social and governance (ESG) issues and their costs and benefits. There has also been an evolution to market-based reporting. Future studies can employ large scale investigations using textual analysis methods from computational linguistics to assess the credibility of the CSR documents as an extension of the work of Nazari et al. (2017).

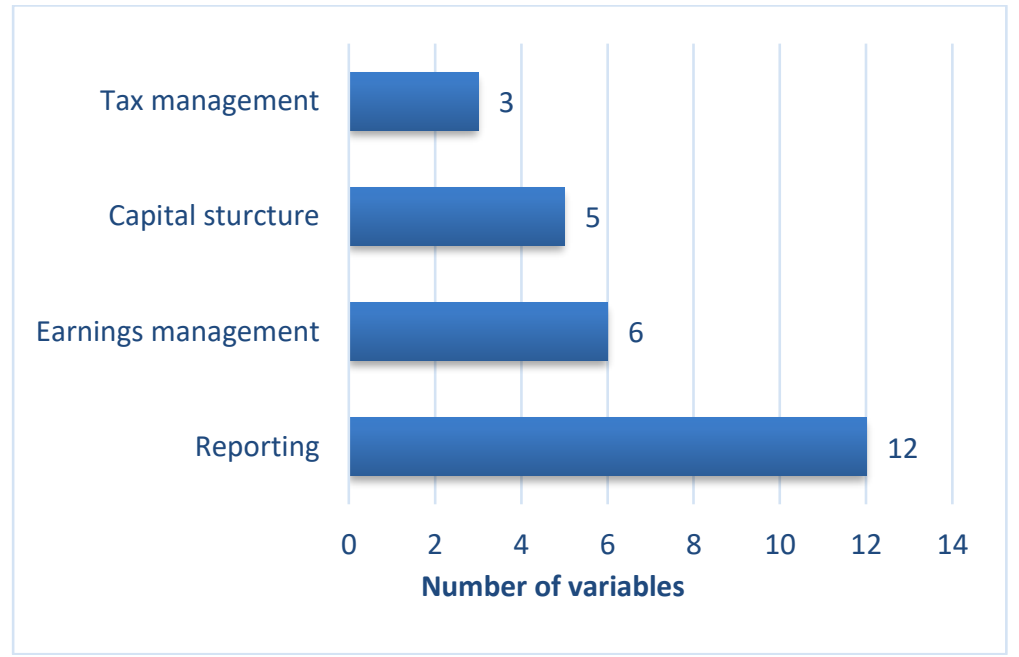

Figure 1 Variables Addressed in CSR Literature Review 


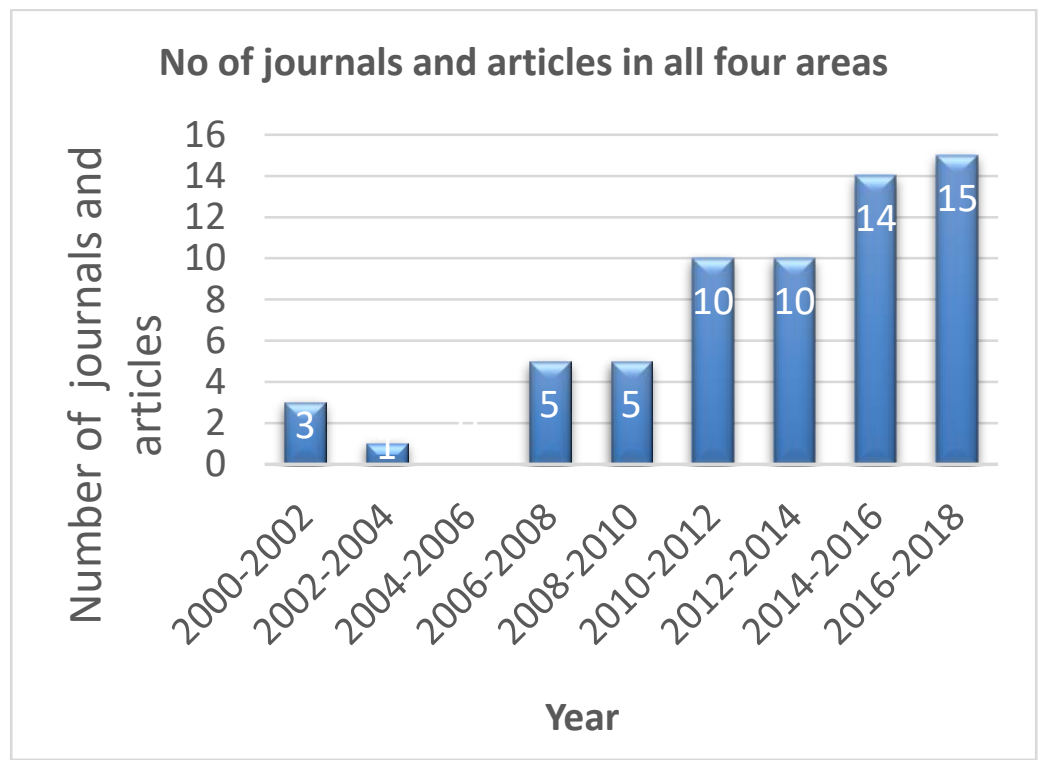

Figure 2 Number of Publications Year Wise Range

Despite the rich literature on an increasing number of subjects related to CSR, there are still many questions that have not received attention. Studies measuring financial risk for CSR are yet to be investigated since environmental risk measures impact on financial risk is rarely quantifiable. The examination of environmental risk using Value at Risk $(V a R)$ models is a step in the right direction. CSR is associated with risk management in which the objective is to avoid potential threats. The role of activist shareholders in influencing how a company reports its CSR needs to be investigated. Empirical analysis on CSR reporting practices and quality of disclosure can employ a larger sample and consider material information for stakeholders. Research surveys on CSR and financial reporting and earnings quality can bring out the practical application of CSR towards economic growth.

Another interesting avenue of research will be the CSR and its financial implication for financial besides non-financial sector. Apart from few researchers like Chih et al. (2010), Wu and Shen (2013), the examination is inadequate because of the complex nature of the financial industry. A major question which could be addressed is whether the financial industry is rewarded for taking social responsibilities.

\section{References}

1. Andrikopoulos, A., Samitas, A., \& Bekiaris, M.; 'Corporate social responsibility reporting in financial institutions: Evidence from Euronext', Research in International Business and Finance, 32, 2014, 27-35. doi: 10.1016/j.ribaf.2014.02.001 
2. Alipour, M., Ghanbari, M., Jamshidinavid, B., \& Taherabadi, A.; The relationship between environmental disclosure quality and earnings quality: a panel study of an emerging market. Journal of Asia Business Studies, 13(2), 2019, 326-347. doi: 10.1108/jabs-03-2018-0084

3. Almahrog, Y., Ali Aribi, Z., \& Arun, T.; Earnings management and corporate social responsibility: UK evidence. Journal of Financial Reporting and Accounting, 16(2), 2018, 311-332. https://doi.org/10.1108/JFRA-11-2016-0092

4. Bae, K; Kang and Wang, J; Employee treatment and firm leverage: a test of the stakeholder theory of capital structure. Journal of financial economics, 100, 2011, 130-153

5. Bae, K., Kwok, C., \& Zheng, Y; Does Corporate Social Responsibility Reduce the Costs of High Leverage? Evidence from Capital Structure and Product Markets Interactions; 2017, SSRN Electronic Journal. doi: 10.2139/ssrn.2959444

6. Ballou, B., Chen, P., Grenier, J., \& Heitger, D; Corporate social responsibility assurance and reporting quality: Evidence from restatements. Journal of Accounting and Public Policy, 37(2), 2018, 167-188. doi: 10.1016/j.jaccpubpol.2018.02.001

7. Becchetti, L., Ciciretti, R., \& Giovannelli, A; Corporate social responsibility and earnings forecasting unbiasedness. Journal of Banking \& Finance, 37(9), 2013, 3654-3668. doi:10.1016/j.jbankfin.2013.05.026

8. Ben Amar, A., \&Chakroun, S; do dimensions of corporate social responsibility affect earnings management? Journal of Financial Reporting and Accounting, 16(2), 2018; 348-370. doi: 10.1108/jfra-05-2017-0033

9. Benlemlih, M.; Corporate social responsibility and firm financing decisions: A literature review. Journal of Multinational Financial Management, 2017, 42-43, 1-10. doi: 10.1016/j.mulfin.2017.10.004

10. Bird, R., \& Davis-Nozemack, K; Tax Avoidance as a Sustainability Problem. Journal of Business Ethics, 151(4), 2016, 1009-1025. doi: 10.1007/s10551-016-3162-2

11. Bozzolan, S., Fabrizi, M., Mallin, C. A., \& Michelon, G; Corporate Social Responsibility and Earnings Quality: International Evidence. International Journal of Accounting, 50(4); 2015, 361-396. https://doi.org/10.1016/j.intacc.2015.10.003

12. Bona Sánchez, C., Pérez-Alemán, J., \& Santana-Martin, D. J; Sustainability disclosure, dominant owners and earnings in formativeness. Research in International Business and Finance, 39, 2017, 625-639. https://doi.org/10.1016/j.ribaf.2016.07.020

13. Business and Development: Challenges and opportunities in a rapidly changing world, WBCSD (World Business Council for Sustainable Development, 2010), $\operatorname{Pg} 1$

14. Carey, P., Liu, L., \& Qu, W; Voluntary corporate social responsibility reporting and financial statement auditing in China. Journal of Contemporary Accounting and Economics, 13(3), 2017, 244-262.

https://doi.org/10.1016/j.jcae.2017.09.002 
15. Carnegie, G. D., \& Napier, C. J; Exploring Comparative International Accounting History. Accounting, Auditing \& Accountability Journal, 15(5), 2002, 689-718.

16. Carroll, A. The pyramid of corporate social responsibility: toward the moral management of organizational stakeholders. Bus. Horiz.,34, 1991, 39-48

17. Col, B., \& Patel, S; Going to Haven? Corporate social responsibility and tax avoidance. Journal of Business Ethics. Advance online publication, 2016 https://doi.org/10.1007/s10551-016-3393-2

18. Desai and Dharmapala; Corporate tax avoidance and high-powered incentives, J. Financ. Econ., 79, 2006, pp. 145-179

19. Cheng, B., Ioannou, I., \& Serafeim, G; Corporate social responsibility and access to finance. Strategic Management Journal, 35(1), 2013, 1-23. doi: 10.1002/smj.2131

20. Chih, H. L., Shen, C. H., \& Kang, F. C.; Corporate social responsibility, investor protection, and earnings management: Some international evidence. Journal of Business Ethics, 79(1-2), 2008, 179-198. https://doi.org/10.1007/s10551-0079383-7

21. Chih, H; Chih, H; Chen, $\mathrm{T}$; on the determinants of corporate social responsibility: international evidence on the financial industry. Journal of business ethics, 93, 2010, 115-135.

22. Choi, B. B., Lee, D., \& Park, Y; Corporate social responsibility, corporate governance and earnings quality: Evidence from Korea. Corporate Governance:

An International Review, 21(5), 2013, 447-467.

https://doi.org/10.1111/corg. 12033

23. Corporate social responsibility (CSR) | Current issues. (2019). Retrieved 20 October 2019, from https://www.iisd.org/business/issues/sr.aspx

24. Credit suisse. (2018). The CS Family 1000 in 2018. Zurich, Switzerland.

25. Dechow, P. M., \&Dichev, I. D.; "The quality of accruals and earnings: The role of accrual estimation errors". The accounting review, Vol.77 No.s-1, 2002,pp. 35-59

26. Dechow, P., Ge, W., \& Schrand, C; "Understanding earnings quality: A review of the proxies, their determinants and their consequences". Journal of accounting and economics, Vol.50 No.2, 2010, pp. 344-401

27. Derwall J, Verwijmeren P; Corporate social responsibility and the cost of equity capital. Working paper, Rotterdam School of Management, Erasmus University, Rotterdam, The Netherlands, 2007.

28. Dowling, G; The Curious Case of Corporate Tax Avoidance: Is it Socially Irresponsible? Journal of Business Ethics, 124(1), 2013, 173-184. doi: 10.1007/s10551-013-1862-4

29. Ellis, L., \& Bastin, C; Corporate social responsibility in times of recession: Changing discourses and implications for policy and practice. Corporate Social Responsibility and Environmental Management, 18(5), 2010, 294-305. doi: 10.1002/csr.254

30. Ferrero-Ferrero, I.; Fernández-Izquierdo, M.; ángeles Muñoz-Torres, M.J.; The effect of environmental, social and governance consistency on economic results. 2016,Sustainability 
31. Feiying He, Qi Zhu \& Shihao Li; How does corporate social responsibility change capital structure? Asia-Pacific Journal of Accounting \& Economics, 25:3-4, 2018,352-387, DOI: 10.1080/16081625.2017.1354710

32. Freeman, R. E., Harrison, J. S., and Wicks, A. C.; Managing for stakeholders: survival, reputation, and success. New Haven, CT: Yale University Press, 2007, United States

33. Friedman, M; The social responsibility of business to increase its profits. The New York Times Magazine, 1; 1970.

34. García-Sánchez, I.-M., \& García-Meca, E; CSR Engagement and Earnings Quality in Banks. The Moderating Role of Institutional Factors. Corporate Social Responsibility and Environmental Management, 24(2), 2017, 145-158.

35. Gergen, K. J; An invitation to social construction. London: Sage, 1999.

36. Girerd-Potin, I., Jimenez-Garces, S., \& Louvet, P; the Link between Social Rating and Financial Capital Structure. Finance, 32(2), 2011，9. doi: 10.3917/fina.322.0009

37. Godfrey, P. C; The relationship between corporate philanthropy and shareholder wealth: A risk management perspective. Academy of Management Review, 30(4), 2005, 777-798.

38. Gras-Gil, E., Palacios Manzano, M., \& Hernández Fernández, J.; Investigating the relationship between corporate social responsibility and earnings management: Evidence from Spain. Business research quarterly, 19, 2016, 289299.

39. Grougiou, V., Leventis, S., Dedoulis, E., \& Owusu-Ansah, S.; Corporate social responsibility and earnings management in U.S. banks. Accounting Forum, 38(3), 2014, 155-169. https://doi.org/10.1016/j.accfor.2014.05.003

40. Guillamón-Saorín, E., Guiral, A., \& Blanco, B; Managing risk with socially responsible actions in firms involved in controversial activities and earnings management. Revista Espanola de Financiacion y Contabilidad, 47(1), 2018, 124. https://doi.org/10.1080/02102412.2017.1346913

41. Hanlon, M., \& Heitzman, S; A review of tax research. Journal of Accounting and Economics, 50, 2010, 127-178.

42. Harjoto, M., \& Jo, H; Legal vs. Normative CSR: Differential Impact on Analyst Dispersion, Stock Return Volatility, Cost of Capital, and Firm Value. Journal of Business Ethics, 128(1), 2014, 1-20. doi: 10.1007/s10551-014-2082-2

43. Hasseldine, J., \& Morris, G; Corporate social responsibility and tax avoidance: A comment and reflection. Accounting Forum, 37(1), 2013, 1-14. doi: 10.1016/j.accfor.2012.05.001

44. Hong, Y., \& Andersen, M. L; the Relationship between Corporate Social Responsibility and Earnings Management: An Exploratory Study. Journal of Business Ethics, 104(4), 2011, 461-471. https://doi.org/10.1007/s10551-0110921gto

45. https://www.business2community.com/socialbusiness/\%E2\%80\%8B\%E2\%80\%8Bhow-corporate-social-responsibility-ischanging-the-way-we-help-the-world-02105239

46. Huseynov, F., \& Klamm, B; Tax avoidance, tax management and corporate social responsibility. Journal of Corporate Finance, 18(4), 2012, 804-827. doi: 10.1016/j.jcorpfin.2012.06.005 
47. J. Guthrie, S. Cuganesan, L. Ward, ; Industry specific social and environmental reporting: The Australian food and beverage industry, Accounting Forum,32 (1),2008, pp. 1-15

48. Jabbour, C.J.C; Environmental training in organisations: From a literature review to a framework for future research. Resour. Conserv. Recycl.74, 2013, 144-155.

49. Corporate governance and corporate social responsibility synergies and interrelationships, D. Jamali, A.M. Safieddine and M. Rabbath, Corp. Gov. Int. Rev., 15,2008, pp. 443-459

50. Jensen, M. and Meckling, W.; Theory of the Firm: Managerial Behaviour, Agency Costs and Ownership Structure. Journal of Financial Economics 3(4), 1976, 305-360.

51. J.D. Margolis, H.A. Elfenbein and J.P. Walsh; Does It Pay to Be Good... and Does It Matter? A Meta-analysis of the Relationship between Corporate Social and Financial Performance. 2009, Working paper, Harvard University

52. J. Elkington; Cannibals with Forks. The Triple Bottom Line of 21st Century, 1997, New Society Publisher

53. Kim, Y., Park, M., Wier, B; is earnings quality associated with corporate social responsibility? Account.Rev, .87(3), 2012, 761-796.

54. Knowledge@Wharton. (2019). How to Manage the Top Five Global Economic Challenges - Knowledge@Wharton. [online] Available at:

https://knowledge.wharton.upenn.edu/article/what-are-the-top-five-challengesfor-international-organizations/ [Accessed 14 Nov. 2019].

55. Kothari, S., Li, X., \& Short, J; The Effect of Disclosures by Management, Analysts, and Business Press on Cost of Capital, Return Volatility, and Analyst Forecasts: A Study Using Content Analysis. The Accounting Review, 84(5), 2009, 1639-1670. doi: 10.2308/accr.2009.84.5.1639

56. KPMG. (2017).The Road Ahead, The KPMG survey of Corporate Responsibility Reporting 2017.KPMG. Retrieved from https://assets.kpmg/content/dam/kpmg/xx/pdf/2017/10/kpmg-survey-ofcorporate-responsibility-reporting-2017.pdf

57. Kreps, D. M; Corporate culture and economic theory. In J. E. Alt \& K. A. Shepsle (Eds.), Perspectives on positive political economy. Cambridge: Cambridge University Press, 1996

58. Lage Junior, M.; GodinhoFilho, M. Variations of the kanban system: Literature review and classification. Int. J. Prod. Econ. 2010, 125, 13-21

59. Laguir, I., Staglianò, R., \& Elbaz, J; Does corporate social responsibility affect corporate tax aggressiveness? Journal of Cleaner Production, 107, 2015, 662675. doi: 10.1016/j.jclepro.2015.05.059

60. Lanis, R., \& Richardson, G; Is Corporate Social Responsibility Performance Associated with Tax Avoidance? Journal of Business Ethics, 127(2), 2014, 439457. doi: 10.1007/s10551-014-2052-8

61. Li, A., \& Xia, X.; Are Controlling Shareholders Influencing the Relationship Between CSR and Earnings Quality? Evidence from Chinese Listed Companies. Emerging Markets Finance and Trade, 54(5), 2018, 1047-1062. https://doi.org/10.1080/1540496X.2018.1434070 
62. Litt, B., Sharma, D., \& Sharma, V; Environmental initiatives and earnings management. Managerial Auditing Journal, 29(1), 2014, 76-106. https://doi.org/10.1108/MAJ-05-2013-0867

63. Liu, M., Shi, Y., Wilson, C., \& Wu, Z; Does family involvement explain why corporate social responsibility affects earnings management? Journal of Business Research, 75, 2017, 8-16. https://doi.org/10.1016/j.jbusres.2017.02.001

64. Mackey A, Mackey TB, Barney JB; Corporate social responsibility and firm performance: investor preferences and corporate strategies, Academy of Management Review 32(3), 2007, 817-835

65. Mahjoub, L. B., \& Khamoussi, H; "Environmental and social policy and earning persistence. Business Strategy and the Environment, 22(3), 2013, 159-172

66. Mahrani, M., \& Soewarno, N; The effect of good corporate governance mechanism and corporate social responsibility on financial performance with earnings management as mediating variable. Asian Journal of Accounting Research, 3(1), 2018, 41-60. https://doi.org/10.1108/ajar-06-2018-0008

67. Martínez-Ferrero, J., Gallego-Álvarez, I., \& García-Sánchez, I. M; A Bidirectional Analysis of Earnings Management and Corporate Social Responsibility: The Moderating Effect of Stakeholder and Investor Protection. Australian Accounting Review, 25(4), 2015, 359-371. https://doi.org/10.1111/auar.12075

68. Maksimovic, V., Titman, S; Financial policy and reputation for product quality. Review of Financial Studies, 4(1) 1991, Pages 175-200

69. McGuire, J., Schneeweis, T., Branch, B., Perceptions of Management Quality and Firm Financial Performance, 1987 (U. o. Massachusetts) (Amherst: Unpublished manuscript).

70. Mihir A. Desai, the Degradation of Reported Corporate Profits, 19 J. ECON. PERSP. 171, 171 (2005)

71. Minnick and Noga; Do corporate governance characteristics influence tax management? J. Corp. Finance, 16, 2010, pp. 703-718

72. Muttakin, B , Khan, Arif and Azim, Mohammad; "Corporate social responsibility disclosures and earnings quality", Managerial Auditing Journal, Vol. 30(3), 2015, pp. $277-298$

73. Moneva, J. M., \&Llena, F; "Environmental disclosures in the annual reports of large companies in Spain". European Accounting Review, 9(1), 2000, pp. 7-29

74. Moratis, L., \& Egmond, M. V; Concealing social responsibility? Investigating the relationship between CSR, earnings management and the effect of industry through quantitative analysis. International Journal of Corporate Social Responsibility, 3(1), 2018. doi: 10.1186/s40991-018-0030-7

75. Michelon, G., Pilonato, S., \& Ricceri, F; CSR reporting practices and the quality of disclosure: An empirical analysis. Critical Perspectives on Accounting, 33, 2015, 59-78. doi: 10.1016/j.cpa.2014.10.003

76. Navarro, P; Why do corporations give to charity? Journal of Business, 1988, 61(1): 65-93. 
77. Nazari, J., Hrazdil, K., \& Mahmoudian, F; assessing social and environmental performance through narrative complexity in CSR reports. Journal of Contemporary Accounting \& Economics, 13(2), 2017, 166-178. doi: 10.1016/j.jcae.2017.05.002

78. Ng, A., \& Rezaee, Z; Business sustainability performance and cost of equity capital. Journal of Corporate Finance, 34, 2015, 128-149. doi: 10.1016/j.jcorpfin.2015.08.003

79. Paine, Lynn Sharp. Value Shift: Why Companies Must Merge Social and Financial Imperatives to Achieve Superior Performance? New York: McGrawHill, 2004

80. Petrovits, C. M; Corporate-sponsored foundations and earnings management. Journal of Accounting and Economics 41(3),2006, 335-36

81. Phillips, N., \& Hardy, C.; Discourse analysis: Investigating processes of social construction (Vol. 50); 2002, Thousand Oaks: Sage University Papers Series on Qualitative Research Methods, Sage.

82. Porter, M., and Kramer, M; Creating Shared Value. Harvard Business Review, 2011, 89 (1/2): 62-77.

83. Preuss, L; Tax avoidance and corporate social responsibility: you can't do both, or can you? Corp. Gov. The International journal of business and society.10, 2010, 365-374.

84. Reputation institute. (2017). 2017 Global CSR RepTrak® Reputation and Corporate

Social

Responsibility.Retrievedfrom:https://www.rankingthebrands.com/PDF/Global\% 20CSR\%20RepTrak\%20100\%202017,\%20Reputation\%20Institute.pdf

85. Richardson, A., \& Welker, M; Social disclosure, financial disclosure and the cost of equity capital. Accounting, Organizations and Society, 26(7-8), 2001, 597-616. doi: 10.1016/s0361-3682(01)00025-3.

86. Scholtens, B., \& Kang, F. C; Corporate Social Responsibility and Earnings Management: Evidence from Asian Economies. Corporate Social Responsibility and Environmental Management, 20(2), 2013, 95-112. https://doi.org/10.1002/csr.1286

87. Sharfman, M. P., \& Fernando, C. S; Environmental risk management and the cost of capital. Strategic Management Journal, 29(6), 2008, 569-592

88. Sen, S., Gurhan-Canli, Z. And Morwitz, V; Withholding Consumption: A Social Dilemma Perspective on Consumer Boycotts. Journal of Consumer Research, 2001, 28(3): 399-417

89. Sial, M., Zheng, C., Khuong, N., Khan, T., \& Usman, M; Does Firm Performance Influence Corporate Social Responsibility Reporting of Chinese Listed Companies? Sustainability, 10(7), 2018, 2217. doi: 10.3390/su10072217

90. Sikka, P; Smoke and mirrors: Corporate social responsibility and tax avoidance. Accounting Forum, 34(3-4), 2010, 153-168.

91. Svensson, G., Ferro, C., Høgevold, N., Padin, C., Carlos Sosa Varela, J., \& Sarstedt, M; framing the triple bottom line approach: Direct and mediation effects between economic, social and environmental elements. Journal of Cleaner Production, 197, 2018, 972-991. doi: 10.1016/j.jclepro.2018.06.226

92. Surroca, J., \& Tribó, J. A.; Are socially responsible managers really ethical? Exploring the relationship between earnings management and corporate social 
responsibility. Corporate Governance: An International Review, 16(3), 2008,160-177. https://doi.org/10.1111/j.1467-8683.2008.00678.

93. Suto, M., \& Takehara, H;CSR and cost of capital: evidence from Japan. Social Responsibility Journal, 13(4), 2017, 798-816. doi: 10.1108/srj-10-2016-0170

94. Suyono, Eko \& Farooque, O. Al; Do governance mechanisms deter earnings management and promote corporate social responsibility? Accounting Research Journal, 31(3), 2018, 479-495. https://doi.org/10.1108/ARJ-09-2015-0117

95. Tschopp, D., \& Huefner, R; Comparing the Evolution of CSR Reporting to that of Financial Reporting. Journal of Business Ethics, 127(3), 2014, 565-577. doi: 10.1007/s10551-014-2054-6

96. Patten, D., \& Zhao, N; Standalone CSR reporting by U.S. retail companies. Accounting Forum, 38(2), 2014, 132-144. doi: 10.1016/j.accfor.2014.01.002

97. Paun, D; Corporate sustainability reporting: An innovative tool for the greater good of all. Business Horizons, 61(6), 2018, 925-935. doi: 10.1016/j.bushor.2018.07.012

98. Porter, M. E. and M. R. Kramer; 'Strategy and Society: The Link Between Competitive Advantage and Corporate Social Responsibility', Harvard Business Review 84(12), 2006, 78-92

99. Weisbach, D. A; An economic analysis of anti-tax-avoidance doctrines. American Law and Economics Review, 4(1),2002, 88-115

100. Whait, R., Christ, K., Ortas, E., \& Burritt, R; Do we know about tax aggressiveness and corporate social responsibility? An integrative review. Journal Of Cleaner Production, 204, 2018, 542-552. doi: 10.1016/j.jclepro.2018.08.33

101. Wang, X., Cao, F., \& Ye, K; Mandatory Corporate Social Responsibility (CSR) Reporting and Financial Reporting Quality: Evidence from a Quasi-Natural Experiment. Journal Of Business Ethics, 152(1), 2016, 253-274. doi: 10.1007/s10551-016-3296-2

102. Yip, E.,Van Staden,C.,Cahan,S.; Corporate social responsibility reporting and earnings management: the role of political costs. Australian Accounting. Bus. Finance J.5(3), 2011, 17-34.

103. Ylönen, M., \& Laine, M; For logistical reasons only? A case study of tax planning and corporate social responsibility reporting. Critical Perspectives on Accounting, 33, 2015, 5-23. doi: 10.1016/j.cpa.2014.12.001

104. Zingales, L; In Search of New Foundations. The Journal of Finance, 2000, 55(4): 1623-1653.

\section{About Our Authors}

Nitika Gaba is a research scholar in Finance at Department of Management Studies, IIT Madras. She has completed her MBA from Ambedkar University Delhi. She has work experience of about one and a half year in investment banking.

R Madhumathi is Professor of Finance in Department of Management Studies, IIT Madras. She has considerable experience in research and in developing online courses for students. She has presented papers at several national and international conferences. She has also published research articles in leading journals. 